\title{
The Emancipation and Liberation of One Karen Smith
}

\author{
Destinee Wilson, Alexandra Lang, and Chloe Campos
}




\section{The Emancipation and Liberation of One Karen Smith}

Set in the late 1910s, a white woman named Karen Smith lives an ordinary life married to her husband in Brooklyn, New York in a lovely home. Brad, the husband of Karen, has a job on Wall Street, where he commutes to work. He is very controlling, misogynist, and racist. They have been married for five years and have a normal and happy life, the complete American Dream. During this time, the women of the United States are embroiled in the fight for suffrage, with many in opposition. Karen and Brad are a part of the anti-suffrage movement that believes in a limited role for women, such as "working in the home." Realizing that the suffrage movement was gaining momentum, Karen decides to infiltrate the National Women's Party. Karen is determined to find out insider information to harm the suffrage movement. While engaging in espionage, Karen discovers herself, makes friends, and decides how she wants to be remembered by history.

Note*** As three young women who are writing this less than a month from a national presidential election, we wanted to tell an objective, passionate story that highlights the journey to the true democracy of women. Historically, the passage of the 19th Amendment, which guaranteed women the right to vote, is one of the most essential and wide-ranging political mobilization movements in all of American history. As monumental as the suffrage movement was, the path to liberation was wrought with difficulty. The movement grappled with the fundamental definition of womanhood and the complete disruption of the status quo. Unfortunately, during this time, the movement was embedded with racial tension, discrimination, and hatred. As diverse and educated women, we wanted to create a story that reversed the silence, erasure, and deep-seated racial prejudice during the 1910s. We wanted to recognize the contributions and perspectives of women of color and the LGBTQIA community. Thus, we categorize this musical as historical fiction. Through this reimagination, we created a musical that is diverse, inclusive, ethical, and enlightening. We wanted to create a dramatic retelling that beautifully details our collective history as women and United States citizens. We hope this musical serves as an example of empowerment and of the necessity for solidarity. 
May more stories capture these ideals and give voices to those silenced, marginalized, and erased. We hope we adequately demonstrate the achievements of those who fought for our rights. Your achievements are recognized and appreciated. We are standing on your shoulders. Thank you. 


\section{Character List}

Karen

Brad

, n

.(Main Character)

White woman with internalized sexism; Stay at home wife; Is sent to spy on the NWP

(Husband of Karen)

Sexist, racist, homophobic, \& etc.; Works on Wall Street.

Chad.

\section{.(Husband's Best Friend)}

Sexist, racist, homophobic, \& etc.

Manuel.

("Manny") (Friend of Brad and Chad)

Not totally sexist but not a complete feminist either; Hispanic

Alice Paul. (Founder/Leader of National Women's

Party)Played by a black woman

Mary Ann Shadd Cary .(Black Feminist Activist)

Betty White (Suffragette)

Old lady, gruff but caring, very passionate

Harriet Wilson. (Suffragette)

Bridgett (Suffragette)

Penny. (Suffragette)

Steven (Ally/Working with the National Women's Party) A gay man 


\section{Song Order}

1. "You Will Still Be Mine" from Waitress (music and lyrics by Sara Bareilles)

2. "I Am Ashamed That Women Are So Simple" from Kiss Me Kate (music and lyrics by Cole Porter)

3. "Salute" by Little Mix

4. "What I Was Born To Do" from Bring it On: The Musical (music and lyrics by Thomas Robert Kitt, Lin-Manuel Miranda, and Amanda Green)

5. "Sports Analogies" from Crazy Ex-Girlfriend (music and lyrics by Adam Schlesinger and Jack Dolgen)

6. "The Man" by Taylor Swift

7. "Brave" by Sara Bareilles and Jack Antonoff

8. "Bad Blood" by Taylor Swift

9. "Get Out and Stay Out" from 9 to 5 The Musical (music and lyrics by Dolly Parton)

10. "This Is For My Girls" performed by Chloe x Halle, Jadagrace, Janelle Monáe, Kelly Clarkson, Kelly Rowland, Lea Michele, Missy Elliot, and Zendaya (written by Diane Eve Warren) 
$B R A D$ and KAREN are at their home in Brooklyn, NY after a meeting at the National Association Opposed to Woman Suffrage, where they discussed the momentum of the current suffrage movement. It was suggested that KAREN join the suffrage movement as a spy to gain insight into their plans.

\section{$B R A D$}

*Reclining in the living room, yelling* You know how important this is to our cause. Men have always had the ability to vote, why should we alter the current state of affairs? The woman's mind is dangerous, and we have a duty to protect you. I think you should do it.

\section{KAREN}

*As she cleans dishes* I don't know. Doesn't it seem a little risky? I mean, what if they find out that I am working for NAOWS. I am just as opposed as you are, but these women are radical, and I'm not a good actress.

\section{BRAD}

Look, putting advertisements in the newspapers isn't enough, we need more. Those "women" want the complete breakdown of the family unit. Do this for us and our future family. Don't you want our children to grow up in a stable society?

\section{KAREN}

You're so right, darling. You know I want our children to have the absolute best. I just don't understand politics like you do. Thank you so much for explaining it to me.

\section{BRAD}

Of course, sweetie. That's what I'm here for. If you just do as I ask, I'll make sure you're well taken care of, like I always have.

\section{"You Will Still Be Mine" from Waitress (lyrics by Sara Bareilles)}

[BRAD:]

Remember my clean shave

Back in our old days

We were just kids

I had my six string

And you had your own thing

Though I don't remember what it is

I wrote you love songs

And you liked that sad one

So, I played it all the time 
What was that one line?

Something 'bout sunshine

I sang it every night

Where the sun don't shine

No, that can't be it

When the sun won't shine

What was it baby?

\section{[KAREN:]}

Till the sun don't shine

You will still be mine

\section{[BRAD:]}

That's right

Man what a whirlwind

So much has happened

And mostly to me

We've come such a long way

No turning back now babe

You're my family

Now promise me

To the end of time

These are ties that bind

Sing it, honey

\section{[KAREN:]}

Till the sun don't shine

[Both:]

You will still be mine

[BRAD:]

Mine

Mine

Mine

*SONG ENDS* 


\section{BRAD}

*Getting up and walking upstairs* I'm going to bed, honey. I've had a long day. Now give us a kiss.

\section{KAREN}

Alright, honey. *Kisses him* Goodnight

KAREN continues washing dishes and cleaning

\section{"I Am Ashamed That Women Are So Simple," from Kiss Me Kate \\ [KAREN]:}

I am ashamed that women are so simple

To offer war where they should kneel for peace,

Or seek for rule, supremacy, and sway

When they are bound to serve, love and obey.

Why are our bodies soft, and weak, and smooth,

Unapt to toil and trouble in the world,

But that our soft conditions and our hearts

Should well agree with our external parts?

So, wife, hold your temper, and meekly put

Your hand 'neath the sole of your husband's foot,

In token of which duty, if he please,

My hand is ready,

Ready,

May it do him ease.

\section{*SONG ENDS*}

THE NEXT DAY, KAREN goes to a women's protest, determined to give credible information back to the NAOWS. She sees a lot of women in "knee-length skirts with full Turkish-style pantaloons gathered at the ankle." (Utech, 2020) Internally, she cringes and scoffs in disgust at their obvious choice of radical clothes. A secret part of her recognized the appeal of the clothing due to the increased mobility, but she quickly dismissed that train of thought. Moving to the front of the crowd, KAREN begins listening to the impassioned woman at the front and the echoes of agreement around her. 
"Salute" By Little Mix

[ALICE:]

Ladies all across the world

Listen up, we're looking for recruits

If you're with me, let me see your hands

Stand up and salute

Get your killer heels, sneakers, pumps or lace up your boots

Representing all the women

Salute, salute!

[BRIDGETT:]

Ladies all across the world

Listen up, we're looking for recruits

If you're with me, let me see your hands

Stand up and salute

Get your killer heels, sneakers, pumps or lace up your boots

Representing all the women

Salute, salute!

\section{[ALL:]}

It's who we are

We don't need no camouflage

It's the female federal

And we're taking off

If you're with me, women, let me hear you say

Ladies all across the world

Listen up, we're looking for recruits

If you're with me, let me see your hands

Stand up and salute

Get your killer heels, sneakers, pumps or lace up your boots

Representing all the women

Salute, salute!

Attention! (salute)

Attention! (salute)

Attention! (huh!)

Representing all the women

Salute, salute!

[BETTY:]

Sisters we are everywhere 
Warriors, your country needs you

If you're ready ladies, better keep steady

Ready, aim, shoot

Don't need ammunition, on a mission

And we'll hit you with the truth

Divas, queens, we don't need no man, salute!

[PENNY:]

Sisters we are everywhere

Warriors, your country needs you

If you're ready ladies, better keep steady

Ready, aim, shoot

Don't need ammunition. On a mission

And we'll hit you with the truth

Representing all the women

Salute, salute!

[ALL:]

It's who we are

We don't need no camouflage

It's the female federal

And we're taking off

If you're with me, women, let me hear you say

\section{[ALL:]}

Ladies all across the world

Listen up, we're looking for recruits

If you're with me, let me see your hands

Stand up and salute

Get your killer heels, sneakers, pumps or lace up your boots

Representing all the women

Salute, salute!

Attention! (salute)

Attention! (salute)

Attention! (huh!)

Representing all the women

Salute, salute!

\section{[ALICE:]}

You think we're just pretty things

You couldn't be more wrong 


\section{[ALL:]}

(We're standing strong, we carry on)

\section{[ALICE:]}

Knock us but we keep moving up (we're moving up, yeah)

Can't stop a hurricane, ladies it's time to awake (yeah!)

\section{[ALL:]}

Attention!

Attention!

Individuals!

Originals!

Huh!

[ALICE:]

Let me hear you say

[ALL:]

Ladies all across the world

Listen up, we're looking for recruits

If you're with me, let me see your hands

Stand up and salute

Get your killer heels, sneakers, pumps or lace up your boots

Representing all the women

Salute, salute!

Attention! (salute)

Attention! (salute)

Attention! (huh!)

Representing all the women

Salute, salute!

\section{[ALICE, ON A MEGAPHONE:]}

Ladies, the time has come; the war has begun. Let us stand together And remember, men fight great, but women are great fighters

Huh!

[ALL:]

Representing all the women 


$$
\text { Salute, salute! }
$$

\title{
*SONG ENDS*
}

After the protest, things are winding down. With groups of women closely scattered discussing the next event. A beautiful black woman with long, curly hair recognizes KAREN, standing isolated and fidgeting from the other members of the National Women's Party. ALICE approaches KAREN.

\author{
ALICE \\ I noticed you standing by yourself. Is it your first time here? \\ KAREN \\ *KAREN primly responds* Yes. \\ ALICE \\ So, what did you think?

\section{KAREN} \\ Well, you certainly are passionate.

\section{ALICE} \\ equal to men, and we should be able to vote like them, too.

\section{KAREN} \\ *KAREN looks around snottily* I see.
}

Well, of course. We are working tirelessly to make sure that women are granted the right to vote. We are citizens

\author{
ALICE \\ What's your name? \\ KAREN \\ I'm Ka--my name is Mable. Mable Peabody.
}

\section{ALICE}

Well, hello, Mable, it's nice to meet you. I'm Alice.

\section{KAREN}

So, Alice, how did you come to be involved in this, er, organization? 
"What I Was Born To Do," from Bring It On, the musical (with original lyrics by Alexandra Lang) [ALICE:]

I was just a girl

Walking down the street

When I saw the Suffragettes march for the first time

Holding up their signs

Calling out for change

I looked around

Do these people see what I see?

Those heroines were going for the win

And when they started to chant I knew

That I would find a way

To be with them one day

Cause in that moment I finally knew

What I was born to do

[ENSEMBLE]

Go, Go, Go ALICE

Go ALICE

Go, ALICE, Go

\section{[ALICE:]}

Made a vow I was gonna be a protester

Like the Suffragettes in front of me

So, I chanted

And I ranted

'Till I made the team

Now my life is doing activism

It's my dream

Slow motion down the hall

As sexists stop and glare

I'm calling for a change in the law

For the first time

And if I ever fall

I know my team is there

Cause I've got the Suffragettes here behind me 
[ENSEMBLE:]

We activists are going to pound our fists

And there is nothing that we can't do

They underestimate

But we'll retaliate

And with our powers combined we do

What we were born to do

Hey-ey-ey-ey

[ALICE:]

Ready, Okay

[PENNY:]

My name is Penny

I rep the 'Gettes with pride

I'm tired of the men who want me just to stand aside

[ENSEMBLE:]

Aww

[BETTY:]

I'm Betty, and petty

Should be my middle name

I may look like a granny

But I never act my age

\section{[BRIDGET:]}

My name is Bridget

I hold the banner sign

It's hot out here

And now the sun is melting the design

\section{[STEVEN:]}

What's up, my name is Steven

I know, this is the way

We're gonna make a difference

Liftin' up the girls and gays 
[ENSEMBLE:]

What!

\section{[STEVEN:]}

Yeah I will fight

And don't care what the sexists say!

How many guys can say

They hang with girls all day

Love you, girl

\section{[ALICE:]}

Love you more

\section{[RANDOM WOMAN:]}

*Sarcastically*Oh, yay, suffragette protests are today

Yippee

\section{[RANDOM MAN:]}

Yeah, yippee.

Even mocking suffragettes cannot hide the emptiness in my soul

\section{[ALICE:]}

Hey, You've never met me face to face

If you think we women are a waste of space

We work

And we fight

And we train and hustle

We get Mani-pedis, but were made of muscle

We'll paint the town with our makeup palette

We're hanging chads 'till we get a ballot

\section{[ALL:]}

This election getting closer by the minute

Last year we got beat

This year we're gonna get it

Bring it! 


\author{
[ALICE:] \\ Calling Congressmen \\ Marking out the route \\ Trying out a brand new chant for the first time \\ Making all the plans \\ Here behind the scenes \\ I look around \\ Do these people see what I see?
}

\title{
[ALL:]
}

These Suffragettes

Are as tough as they get

We've got the spirit and we'll see it through

So, watch what happens then

'Cause we will not give in

Because we're doing what we're born to do

Doing what we're born to do

\section{[ALICE:]}

Doing what I'm born to do

There is so much more to do

I can see it in my mind

The future's ours

When we get the vote

We'll know it's worth the hours

We will march the streets of this country far and wide

We will all unite, not a woman left behind

We will take this fight to the street

We are used to pain in our feet

'Cause this is why we were born

So now we're gonna write all womankind in the sequel

C'mon pick up the pace, never stop 'till we're equal

We're only at the start, we got nothin' to lose

'Cause this is what we're born to do, so let's do it!

\section{*END OF SONG*}

\section{ALICE}

So, you see. *ALICE brightly smiles* Let me introduce you to everyone. Ladies, this is Mable. She's new here. Mable, this is everyone. Our leaders are Mary Ann, Betty, and Harriet. Our members are Bridgett, Penny, and 


\section{KAREN}

Nice to meet you all.

MARY ANN throws up a brief wave, and starts to leave, explaining she needs to get home to her children. BETTY simply grunts in greeting and goes back to her previous conversation. BRIDGETT, PENNY, and STEVEN continue to clean, shouting out brief greetings. HARRIET excitedly greets KAREN.

\section{HARRIET}

Hello Mable! How are you? Oh, it's so great to meet you and have you here! We need all the help we can get! Are you tired? I know how the first protest can be so overwhelming to the newbies!

*ALICE sees KAREN get increasingly uncomfortable and quickly jumps in.*

\section{ALICE}

So, Mable, do you want to join us?

\section{KAREN}

*KAREN takes a long pause, then remembers her promise to Brad* Yes, I would. Thank you.

\section{ALICE}

Wonderful! Walk with me, and I'll give you more details

*The women exit the stage, marching and chanting.*

*END SCENE*

*NEW SCENE*

The next night while KAREN is doing recon at the meeting. Her husband, BRAD, is meeting with his friends

CHAD and MANUEL. They are drinking and smoking in a cigar lounge, wearing thick velvet robes. The lounge has expense furniture covered in leather. They are in a calm argument, where CHAD cannot fathom why BRAD would let KAREN be around such radical women. CHAD warns that it could be a mistake that will drastically change KAREN and make her want more freedom.

\section{CHAD}

Brad, how can you let Karen run amongst those hooligan women! Aren't you concerned she might reveal herself- or worse, befriend them? You know how hysterical women can be. 


\section{BRAD}

Relax, my good man, Karen, is a tame woman. She follows my orders as any good wife. Believe me. I've trained her well.

\section{*The three of them laugh.* \\ MANUEL}

But, seriously, aren't you even slightly concerned. My friend lost his wife to those extremist women.

\section{BRAD}

Yes, but your friend's wife didn't have my Karen's loyalty. She's like a puppy dog, that one. You have to satisfy your wife. That's how you keep her in check.

\section{CHAD}

Manuel, your friend's wife was a bit loco. . . .

\section{WAITER}

Excuse me, er, Senor. But I'm going to have to ask you to move to the other side of the lounge. Your. . . kind. . . . isn't welcome here.

\section{BRAD}

Don't worry, Manny, here, is with us.

\section{CHAD}

Yeah, he's not a real Mexican.

*The two of them laugh, and the waiter nods and walks off. MANUEL stays silent.*

\section{BRAD}

Did either of you catch the game on the radio last night?

\section{CHAD}

Of course! I wouldn't have missed it.

\section{MANUEL}

Yes, I listened to it. 


\section{BRAD}

Man, there's nothing I love more than a good game.

\section{CHAD}

Same here

\section{MANUEL}

Me too.

\section{BRAD}

Maybe if those Suffragettes out there listened to a baseball game between their little shopping sprees, they'd quit wasting their time with these protests.

\section{CHAD}

*Smirks*'That's why we men are the ones that know how to score.

\section{BRAD}

That's true, my good sir. But really, what are we to do about these women! They're completely dismantling the system when there's no need! It works great!

\section{CHAD}

Works great for me! Why are they complaining? They choose what lipstick to wear. Why do they need to choose the president? It's a man's job.

\section{BRAD}

I don’t know why they're so crazy, but we have to take our country back!

\section{"Sports Analogies" from Crazy Ex-Girlfriend \\ [BRAD:]}

We're down for the count

It's down to the wire

We can't drop the ball

We gotta aim a little higher

\section{[CHAD:]}

'Cause when we're on the ropes 
And it's our turn at bat

We gotta throw a Hail Mary

Gotta go to the mat

\section{[ALL 3:]}

Sports analogies

Sports analogies

\section{[MANUEL:]}

We've found the common ground

In all men's personalities

\section{[CHAD:]}

We talk a big game

That's how we relate

[ALL 3:]

It's the easiest way for men to

Communicate

\section{[BRAD:]}

Hike!

\section{[CHAD:]}

It's par for the course

[BRAD:]

When you're in the home stretch

\section{[CHAD:]}

To swing for the fences

\section{[BRAD:]}

With a full court press

\section{[CHAD:]}

We're on the one-yard line 


\section{[MANUEL:]}

Inches to go

\section{[CHAD:]}

So you'll pitch and I'll catch

\section{[BRAD:]}

'Cause it's our lead to blow

\section{[ALL 3:]}

Let's use more

Sports analogies

Sports analogies

They help men cope with life's

Harsh realities

\section{[CHAD:]}

Let's spew more clichés

\section{[BRAD:]}

'Til we run out the clock

\section{[MANUEL:]}

Just keep your eye on the ball

\section{[BRAD:]}

The puck

\section{[CHAD:]}

And my shuttlecock

\section{[ALL 3:]}

Hey!

Sometimes, when we watch sports,

We get sad

And we make it seem like

We're sad about the sports 


\section{[CHAD:]}

But we're not really crying

About the game at all

\section{[BRAD:]}

Who really cares about

A game of basketball

\section{[ALL 3:]}

We're sad about our dads

We couldn't talk to our dads

Unless we used

Sports analogies

Sports analogies

Men feel safe with these

Empty generalities

\section{[BRAD:]}

Let's go for the gold

\section{[CHAD:]}

And then we'll hit the lockers

\section{[ALL 3:]}

We're American men

We like all sports except for soccer

'Cause soccer's just a bunch

Of foreigners running around

Yeah!

*SONG ENDS*

*NEW SCENE*

While BRAD is meeting with his friends, KAREN is walking to her first National Women's Party meeting. She's also making notes in a notebook about what she's learned. 


\title{
KAREN (monologue)
}

The audacity of these women! Gallivanting around town with this ridiculous idea. They should be home, caring for their children and preparing the house for their husbands! That is all a woman should do--that is what women were made for. It is sickening. Brad was right, as always. These women need to be stopped before they mess up everything for society.

KAREN arrives at the meeting and promptly takes a seat in the back of the room. As the meeting starts, KAREN tightly holds her purse in her lap, shifting every few seconds. She continuously glances at the door and the worn clock on the wall. She quickly glances up when she hears movement. She is so lost in thought she doesn't hear ALICE assigning duties for each of the women. KAREN suddenly notices that all of the women are talking and doing task. ALICE approaches KAREN.

\section{ALICE}

Hi Mabel, it's great to see you!

\section{KAREN}

Likewise.

\section{ALICE}

Today, we're going to work on publications and advertisements to counter the narrative of NAOWS. They've been publishing disturbing depictions and cartoons of NWP.

\section{KAREN}

Oh, such as?

\begin{abstract}
ALICE
Just terrible depictions of us. Cartoons of husbands suffering as they hold children while the wife stubbornly refuses to help.

KAREN

*Chokes back a laugh* Right. How terrible.
\end{abstract}

\begin{abstract}
ALICE
We aren't opposed to women who want to raise a family. We simply want to offer women the choice, and part of that goal is giving women the right to vote.
\end{abstract}




\title{
KAREN
}

Right, sure.

\begin{abstract}
ALICE
So, do you want to work together?
\end{abstract}

\section{KAREN}

Alright. Thank you.

\section{ALICE}

Sure.

*They sit down and start working.*

\section{ALICE}

So, are you from around here?

\section{KAREN}

I live in the suburbs of Brooklyn, but my husband commutes to the city regularly.

\section{ALIGE}

Your husband? How long have you been married?

\section{KAREN}

We just celebrated our five-year anniversary.

\author{
ALICE \\ Oh, congratulations! \\ KAREN \\ Thank you. And yourself? Are you married?
}

\section{ALICE}

No, and I don't plan on it. 


\title{
KAREN
}

Why not?

\section{ALICE}

I don't know if I want my identity completely tied to a man. When my mother married my father, she was attending Swarthmore, but she had to drop out since married women weren't allowed to attend school.

\section{KAREN}

Oh. Maybe it was for the best.

\section{ALICE}

*Glances sharply at KAREN*I don't really think so.

\section{KAREN}

But if she was in school, she wouldn't have had the time to raise you.

\begin{abstract}
ALICE
*Shaking her head, slowly* That's not for the government to decide. How she spends her time, divided between school or work and family, should have been up to her and my father.

*KAREN is silent for a moment, still unable to fathom why ALICE would create NWP, asks her a blunt question.*

\section{KAREN}

Why did you create the NWP?

\begin{abstract}
ALICE
Ah, women always ask me this question. I think they expect me to describe some epiphany moment, but I have always been this way, a woman striving for equality. See, I grew up in England. I lived in a Quaker household. We tend to believe in the equality of the sexes. From the first time, I learned that being a woman means being treated differently, I knew something should change. We should be equal.
\end{abstract}

\section{KAREN}

It has to be more than that. Surely you weren't born with this. . . .ideology. 


\title{
ALICE
}

*Shrugs* It really isn't though. It may seem insane to women and men that I would subject myself to this treatment. *Holds up a particularly derogatory publication* I just feel like this is my purpose.

*KAREN continues to stare in bewilderment at ALICE*

\begin{abstract}
ALICE
*Slightly chuckles* Let me tell you a story. There was this one time that my friends and I planned a public event with her two friends in Washington D.C. for suffrage. I was so excited, and I hoped that planning it during President Wilson's inauguration would bring national attention and give the movement momentum.

\section{KAREN}

*Gasp* You planned it during the inauguration?

ALICE

*Loudly laughing* Don’t look at me like that. Yes, I did, and I don’t regret it.

\section{KAREN}

I can’t imagine that your march went well.
\end{abstract}

\begin{abstract}
ALICE
*Sighs and somberly looks off into the distance* You are right about that. Everything started off really well, but things got very ugly. First, men were yelling slurs and insults at us, like how unpatriotic we were. Then men began to attack us. *Holding back tears* I still remember screaming and being hit. I looked up and called for anyone to help us, but no one reacted. In fact, the police stood by and watched.
\end{abstract}

*KAREN feels sadness and deep sympathy*

KAREN

That sounds awful.

ALICE

*Shaking herself out of a trance, quickly wipes her eyes to remove the few tears that slipped out* Yeah, it was, but one good thing came out of it.

\section{KAREN}




\begin{abstract}
ALICE
Well, we did end up getting national attention. Plus, ever since we were attacked, I have been completely devoted to equality. I cannot imagine spending my time and energy on anything else. There was something about facing that violence that made me determined to change everything for women.
\end{abstract}

\title{
"The Man" by Taylor Swift
}

\section{[ALICE:]}

I would be complex, I would be cool

They'd say I played the field before I found someone to commit to

And that would be okay for me to do

Every conquest I had made would make me more of a boss to you

I'd be a fearless leader

I'd be an alpha type

When everyone believes ya

What's that like?

I'm so sick of running as fast as I can

Wondering if I'd get there quicker if I was a man

And I'm so sick of them coming at me again

'Cause if I was a man, then I'd be the man

I'd be the man

I'd be the man

They'd say I hustled, put in the work

They wouldn't shake their heads and question how much of this I deserve

What I was wearing, if I was rude

Could all be separated from my good ideas and power moves

And they would toast to me, oh, let the players play

I'd be just like Leo in Saint-Tropez

I'm so sick of running as fast as I can

Wondering if I'd get there quicker if I was a man

And I'm so sick of them coming at me again

'Cause if I was a man, then I'd be the man

I'd be the man

I'd be the man

What's it like to brag about raking in dollars

And getting $b^{*}$ tches and models?

And it's all good if you're bad

And it's okay if you're mad 
If I was out flashing my dollars

I'd be a b*tch, not a baller

They'd paint me out to be bad

So, it's okay that I'm mad

I'm so sick of running as fast as I can

Wondering if I'd get there quicker if I was a man

And I'm so sick of them coming at me again

'Cause if I was a man

Then I'd be the man

I'm so sick of running as fast as I can

Wondering if I'd get there quicker if I was a man

And I'm so sick of them coming at me again

'Cause if I was a man, then I'd be the man

I'd be the man

I'd be the man

I'd be the man

I'd be the man

If I was a man, then I'd be the man

*SONG ENDS*

*END SGENE*

*NEW SCENE*

KAREN is at home with BRAD. They're eating dinner.

KAREN

How was your day?

BRAD

Good. I had cigars and drinks with Chad and Manny after work.

\section{KAREN}

Oh? How was that?

\section{BRAD}

It was fun, as always. How was your day? Did you go to the meeting? 


\section{KAREN}

Yes, of course.

\section{BRAD}

And? What did you learn?

\section{KAREN}

They are very passionate about their cause. They want to make publications to spread around the city.

\section{BRAD}

*Laughs* As if they could come up with something better than NAOWS. I'd like to see them try.

\section{KAREN}

*Chuckles awkwardly* You're so funny, darling

\section{BRAD}

*Smirks* I know. So, what was it like in there, with all those shrewish women?

\section{KAREN}

*Thinking back to the emotion and passion of $A L I C E^{*}$ They were okay.

\section{BRAD}

*Laughing* Okay, *Pft!* Tell me more, I'm sure they were horrid. It is almost criminal what they are doing. I can't believe they want to "vote," knowing they need to be focused on their families.

\section{KAREN}

*Responds nervously* I don't know honey. Some of their stories were really sad, and I understand their perspective a little more.

\section{BRAD}

*Abruptly stops eating* What did you just say?

\section{KAREN}

*Replies tense and timid* No, I just meant that. . . * *stops in the middle of her sentence* You know what, never mind, they're wrong. I don't want the right to vote. I have everything I need. 


\section{BRAD}

*Glancing at KAREN suspiciously* Exactly, a lot of women don't even want to vote. Men and women should have separate responsibilities, I don't understand why women want to change that. Whatever, at least we will get information to stop them. *After, quickly finishing his food. BRAD gets up from the table rubbing his stomach*

Well that was good, honey. I'm going to bed; I had a long day. Goodnight, honey.

*BRAD gives his wife a chaste kiss as he is walking away he looks sternly at KAREN*

\section{BRAD}

Don't forget your purpose when you go to those meetings.

\section{KAREN}

Of course, my darling.

KAREN slowly cleans up after dinner, pondering her day. She thinks about what ALICE said and then what $B R A D$ said. She starts to feel conflicted, wondering what is right. She sighs.

\section{KAREN}

What if he's wrong?

\section{THE LIGHTS SLOWLY DIM WITH HER AT THE SINK, THINKING}

\section{*END SCENE*}

\section{*NEW SCENE*}

KAREN is at another NWP meeting. KAREN and ALICE continue working on the publications. KAREN is starting to make connections with the other ladies and learn their idiosyncrasies. She is particularly fond of BETTY, who is gruff but cares about all of the ladies. She starts to look at the ladies in a new light and is drawn to ALICE. She starts to forget her mission.

\section{ALIGE}

*Laughing so hard she has tears forming* So, then what did you do?

\section{BETTY}

I swung my purse at him!

\section{KAREN}

*Gasps* You did?! 


\title{
BETTY
}

He had it comin'. He was being disrespectful.

\begin{abstract}
ALICE
He deserved that and more. I say you were too easy on him.

*They all laugh*

BRIDGETT

Once, at church, a man told me I was being unfaithful for being a Suffragette.

\section{BETTY}

He did?

\section{BRIDGETT}

Yep. He said I'd have to choose between my Christianity and my political beliefs.
\end{abstract}

\section{ALICE}

That's ridiculous.

\section{BRIDGETT}

That's what I told him. His face got so red and animated; he was flapping his arms like a bird. The Reverend had to ask him to leave!

\section{*They all laugh*}

\section{PENNY}

My ex-husband made me do all the cooking and cleaning around the house! And he never let me get a job!

\section{ALICE}

That's terrible!

\section{KAREN}

Hold on, what? How is that terrible? Isn't that what women are supposed to do?

\section{ALICE}

Not unless they choose to. They shouldn't be forced to follow their husband's orders all the time. 


\section{KAREN}

I do all the cleaning and cooking at my house, is that bad?

\section{BRIDGETT}

It's only bad if you're unhappy with that. Is that what you want to do?

\section{KAREN}

I don't know. It's what my Momma did, and her Momma before her.

\section{ALICE}

Sure, Mabel, but is that what you want? Have you ever wanted to get a job?

\section{KAREN}

Oh, I don't know. . . Maybe when I was younger I wanted to be a veterinarian.

\section{PENNY}

Oh, that's wonderful!

\section{ALICE}

Why didn't you?

\section{KAREN}

*Scandalized*A woman? As a doctor? I've never heard of such a thing. A nurse, perhaps, but a doctor?

\section{ALICE}

But why couldn't it be you?

\section{BETTY}

Mable, are you happy with your life with your husband?

\section{KAREN}

I'm satisfied.

\section{BETTY}

I didn't ask if you're satisfied. I asked if you're happy. 


\title{
KAREN
}

*Thinking in silence for a long moment* I. . . no. I'm not happy.

\section{ALICE}

Then you should tell him!

\section{KAREN}

\author{
But-I love my husband.
}

\section{BRIDGETT}

No one's telling you to leave him. But tell him how you feel!

\section{KAREN}

But. .. . How?

\section{"Brave" by Sara Bareilles \\ [ALICE:]}

You can be amazing

You can turn a phrase into a weapon or a drug

You can be the outcast

Or be the backlash of somebody's lack of love

Or you can start speaking up

\section{[PENNY:]}

Nothing's gonna hurt you the way that words do

When they settle 'neath your skin

Kept on the inside and no sunlight

Sometimes a shadow wins

But I wonder what would happen if you

\section{[ALL:]}

Say what you wanna say

And let the words fall out

Honestly, I wanna see you be brave

With what you want to say

And let the words fall out 
Honestly, I wanna see you be brave

I just wanna see you

I just wanna see you

I just wanna see you

I wanna see you be brave

I just wanna see you

I just wanna see you

I just wanna see you

I wanna see you be brave

[BETTY:]

Everybody's been there

Everybody's been stared down by the enemy

Fallen for the fear

And done some disappearing

Bow down to the mighty

Don't run, stop holding your tongue

[ALICE:]

Maybe there's a way out of the cage where you live

Maybe one of these days you can let the light in

Show me how big your brave is

\section{[ALL:]}

Say what you wanna say

And let the words fall out

Honestly, I wanna see you be brave

With what you want to say

And let the words fall out

Honestly, I wanna see you be brave

\section{[ALICE:]}

And since your history of silence

Won't do you any good

Did you think it would?

Let your words be anything but empty

Why don't you tell them the truth? 


\section{[ALL:]}

Say what you wanna say

And let the words fall out

Honestly, I wanna see you be brave

With what you want to say

And let the words fall out

Honestly, I wanna see you be brave

I just wanna see you

I just wanna see you

I just wanna see you

I wanna see you be brave

I just wanna see you

I just wanna see you

I just wanna see you

See you be brave

I just wanna see you (yeah)

I just wanna see you (oh o)

I just wanna see you

I just wanna see you

I just wanna see you

I just wanna see you

\section{*SONG ENDS*}

\section{KAREN}

You're right. I'm gonna do it.

*They all cheer*

*END SCENE*

*NEW SGENE*

KAREN comes home determined by the other ladies to tell BRAD how she feels. BRAD is completely unaware that KAREN is unhappy. KAREN decides to tell BRAD about her unhappiness during dinner. KAREN nervously fidgets and chews her food. She is so scared about telling BRAD. He notices KAREN's unusual behavior,

but he doesn't say anything. 


\section{BRAD}

So how was your day honey?

\section{KAREN}

*Swallowing nervously* It was good. How was your day?

\section{BRAD}

It was great, just the usual. I am thinking that we should-

\section{KAREN}

*Cuts BRAD off sharply* I think we should talk--

\section{BRAD}

Don't interrupt me, sweetheart.

\section{KAREN}

Oh, I'm sorry.

\section{BRAD}

It's alright. I was thinking, we didn't really get to celebrate our anniversary, did we?

\section{KAREN}

Well I understand. You had to work.

\section{BRAD}

Well, I want to make it up to you. How about we go upstate this weekend?

\section{KAREN}

$\mathrm{Oh}, \mathrm{I}^{-}$

\section{BRAD}

It'll be great, I know it. Now doesn't that sound--

\section{KAREN}

Brad, I want to talk about us 


\section{BRAD}

*Slowly puts down his silverware.* What about us?

\section{KAREN}

Are you happy?

\section{BRAD}

\section{Happy? Of course, I'm happy!}

\section{KAREN}

*Wringing her hands and fidgeting in her seat* Well, I don't think I am.

\section{BRAD}

What are you talking about? Of course, you're happy. Where is this coming from?

\section{KAREN}

Well, I was just talking to the ladies. . . .

\section{BRAD}

What ladies? *Chuckles* You don’t have any friends.

\section{KAREN}

The ladies at the NWP.

\section{BRAD}

*Looks at her in disbelief* You can't be serious.

\section{KAREN}

I am. I'm sorry if-

\section{BRAD}

*BRAD slams his hands on the table* They corrupted you. I knew this would happen. I just knew it! Chad warned me about this.

\section{KAREN}

I'm not corrupted! I just want to be fulfilled and happy. But I love you and-- 


\section{BRAD}

I can't even look at you. I thought you were stronger than this! I can't believe you are letting those "women" influence you.

\section{KAREN}

They didn't! They just opened my eyes to what's going on around me--to my life!

\section{BRAD}

I'm going out. Don't wait for me.

\section{KAREN}

*Holding back tears* Wait, Brad.

*BRAD leaves walking right past her, not even looking at her. KAREN sits at the dinner table looking at the meal she prepared, silently crying**

*END SCENE*

*NEW SCENE*

$B R A D$ is once again meeting with his friends, CHAD and MANUEL at the lounge. BRAD is very concerned, stressed, and tense, silently looking into his drink.

\section{CHAD}

Man, what is your problem? You've been quiet this whole night.

\section{BRAD}

*Long heavy sigh* Nothing man! *Rubs his face and neck* It's just that Karen is acting very differently. She started saying something about not being happy. I think the nasty women at the NWP are influencing her and putting bad ideas in her head. It's like she's a different person.

\section{CHAD}

*Sits back in his seat cockily* What did I tell you man. I knew this was a bad idea.

\section{BRAD}

I don't want to hear that, Chad 


\section{MANUEL}

*Sensing the rising tension, quickly interrupts* I'm sorry, Brad. Did she tell you what she was unhappy about?

\section{BRAD}

*Shaking his head sadly* I just left. I couldn't sit there and let her talk to me like that.

\section{MANUEL}

*Looking calmly at BRAD* Don't you think you should have let her finish. I mean, I'm sure it took a lot for her to talk to you, and you just stormed out. Maybe. . .

\section{CHAD}

*Rudely interrupts MANUEL, talking over him loudly* You should get back at those women and Karen.

\section{BRAD}

*Somberly looking at CHAD* I don't want to hurt Karen, she's my wife.

\section{CHAD}

*Rolls his eyes* Fine. Whatever, but you need to put those NWP women in their place. I wonder how they would feel if they knew Karen was trying to find out information about them to bring them down.

\section{MANUEL}

*Sharply looking at CHAD with blatant disappointment* I dislike NWP too, but that's a terrible idea! I'm sure that would end up harming Karen. Do not listen to Chad.

*BRAD thinks about what CHAD said*

*He keeps on having flashbacks to his conversation with KAREN and becomes increasingly angry.*

\section{BRAD}

That sounds like a good idea, then Karen can stop being with those women and go back to normal.

\section{MANUEL}

*Shaking his head in disbelief* Do you guys hear yourselves? Brad, I thought you said you didn't want to hurt Karen. This will hurt her. From what you say she values these ladies' opinions. 


\section{BRAD}

*Narrowing his eyes at MANUEL* That is precisely the problem. She is listening to those crazy women and their opinion. She should only be listening to me. She will understand that I'm doing this for her benefit. For us.

\section{MANUEL}

*Looking resigned*I don’t think this is going to turn out the way you want it to.

\section{CHAD}

*Cockily grinning* It is about time that you started listening to me. Let me tell you how to do it.

\section{*END SCENE*}

\section{*NEW SGENE*}

BRAD decides to tell the ladies at NWP through an anonymous note about KAREN working as a spy to get information for NAOWS. The ladies at NWP are furious and decide collectively to confront KAREN. KAREN, is unaware that the ladies know her secret and her opinion about them has changed. She actually believes in the movement. KAREN walks into the meeting feeling sad about her conversation with BRAD and how he has been ignoring her. She immediately becomes happy when she walks into the NWP and sees all of the ladies.

\section{KAREN}

Hey ladies, how is everyone doing!

*ALICE stares at KAREN sadly and silently*

\section{BETTY}

*Approaches KAREN fast and shouting*YOU HAVE A LOT OF NERVE COMING IN HERE! WHAT IS WRONG WITH YOU!

\section{BRIDGETT}

*Seeing the anger of BETTY, quickly grabs her arm to stop her approach* She is not worth it, calm down!

\section{KAREN}

What is going on?!

\section{PENNY}

*Waving the note that BRAD left* THIS IS WHAT IS GOING ON! 
KAREN slowly walks to grab the piece of paper and reads it, instantly recognizing $B R A D$ 's handwriting. A sense of foreboding washes over her.

KAREN

I CAN EXPLAIN! IT'S NOT WHAT YOU THINK!

\section{BETTY}

FORGET EXPLAINING! IS IT TRUE?!

\section{KAREN}

*Looking sadly at ALICE* Yes, but-

\section{BETTY}

OH, I KNEW IT! THERE HAS BEEN SOMETHING OFF ABOUT YOU THIS WHOLE TIME! HOW COULD YOU DO SOMETHING LIKE THIS, MABEL?! OR SHOULD I SAY, KAREN?!

\section{BRIDGETT}

*Talking over BETTY's shouting* CALM DOWN BETTY!

\section{BETTY}

*Getting increasingly mad and yelling at the top of her lungs* CALM DOWN? CALM DOWN? *Wildly looking around at the other women* WHY ARE YOU NOT MORE UPSET? YOU KNOW WHAT SHE DID AND HOW THIS COULD HARM US.

\section{"Bad Blood"}

[BETTY:]

'Cause, baby, now we got bad blood

You know it used to be mad love

So take a look what you've done

'Cause, baby, now we got bad blood

Hey

Now we got problems

And I don't think we can solve them

You made a really deep cut

And, baby, now we got bad blood

Hey 


\section{[ALICE:]}

Did you have to do this? I was thinking that you could be trusted

Did you have to ruin what was shiny? Now it's all rusted

Did you have to hit me, where I'm weak? Baby, I couldn't breathe And rub it in so deep, salt in the wound like you're laughing right at me

Oh, it's so sad to think about the good times, you and I

\section{[ALL:]}

'Cause, baby, now we got bad blood

You know it used to be mad love

So take a look what you've done

'Cause, baby, now we got bad blood

Hey

Now we got problems

And I don't think we can solve them

You made a really deep cut

And, baby, now we got bad blood

Hey

\section{[BRIDGETT:]}

Did you think we'd be fine? Still got scars on my back from your knife So don't think it's in the past, these kinda wounds they last and they last. Now did you think it all through? All these things will catch up to you And time can heal but this won't, so if you're coming my way, just don't

\section{[ALL:]}

Oh, it's so sad to think about the good times, you and I

'Cause, baby, now we got bad blood

You know it used to be mad love

So take a look what you've done

'Cause, baby, now we got bad blood

Hey

Now we got problems

And I don't think we can solve them

You made a really deep cut

And, baby, now we got bad blood

Hey 


\section{[ALICE:]}

Band-aids don't fix bullet holes

You say sorry just for show

If you live like that, you live with ghosts (ghosts)

Band-aids don't fix bullet holes (hey)

You say sorry just for show (hey)

If you live like that, you live with ghosts (hey)

Mhmmm

If you love like that blood runs cold

[ALL:]

'Cause, baby, now we got bad blood

You know it used to be mad love (mad love)

So take a look what you've done

'Cause, baby, now we got bad blood

Hey

Now we got problems

And I don't think we can solve them (think we can solve them)

You made a really deep cut

And, baby, now we got bad blood

(Hey)

'Cause, baby, now we got bad blood

You know it used to be mad love

So take a look what you've done (look what you've done)

'Cause, baby, now we got bad blood

Hey

Now we got problems

And I don't think we can solve them

You made a really deep cut

And, baby, now we got bad blood

Hey

*SONG ENDS*

*PENNY Has been silently looking at KAREN. She has tears running down her face.*

PENNY

*Quietly but strongly* You need to leave.

*KAREN is still in shock, realizing her life is shattering in front of her. She looks to ALICE begging for the chance to explain.* 


\section{ALICE}

I agree with Penny, you need to leave. We can't trust you.

*KAREN is begging ALICE with her eyes, but notices that ALICE isn't even looking at her anymore. Feeling immense heartache, KAREN turns slowly and goes to the door.*

\section{BETTY}

*Yelling at KAREN'S retreating figure* Good riddance! Don't you ever come back!

*KAREN looks at the women that she considers friends. She slowly leaves, crying.*

*END SCENE*

*NEW SCENE*

KAREN goes home to prepare a meal for BRAD. For the first time, KAREN feels immense anger at $B R A D$. She is slamming dishes and cooking angrily. BRAD, happy with himself for sabotaging $K A R E N$, is optimistic that he will have his wife back. BRAD enters the house, whistling. KAREN, shaking with rage, simply watches $B R A D$.

\section{BRAD}

*Completely unaware of the anger of his wife* How was your day honey?

\section{KAREN}

*Narrowing her eyes* It was horrible.

\section{BRAD}

Oh, really. That's unfortunate. My day was good, I-

\section{KAREN}

Aren't you going to ask me why it was horrible?

\section{BRAD}

*Sighs heavily and in a patronizing manner* Look if it is about those hags at NWP, I don't want to hear it.

\section{KAREN}

*Slamming a pot down*Oh, believe me you are going to hear this! Why would you write a note like that! 


\section{BRAD}

I did it for us! You have been acting completely differently, and it was because of those women. They were radicalizing you! I don't want you to ever go around those women again!

\section{KAREN}

But they were my friends! You took away the only friends I've had since we got married.

\section{BRAD}

\section{You're friends with Chad's wife!}

\section{KAREN}

No, YOU are friends with CHAD! I make polite small talk with his wife in the kitchen while you two get drunk in the living room.

\section{BRAD}

Look, if you feel guilty about gathering intel to bring them down, we can find other ways-

\section{KAREN}

*Shouting near her breaking point* This isn't just about guilt! I stand with them, and I believe in what they're fighting for! And best of all, they believe in me, which is more than I can say about you!

\section{BRAD}

*Folding his arms, glaring at KAREN*What is that supposed to mean! I AM YOUR HUSBAND! I'm all you need!

\section{KAREN}

STOP telling me what I need! I am a human being and I deserve to be treated like one! I can have my own life outside of you!

\section{BRAD}

*Staring at KAREN strangely* Do you hear yourself? What's wrong with you?!

\section{KAREN}

Do you hear yourself, Brad? You're standing there, telling me that you have this power over me just because you're my husband, and not long ago I would have agreed with you. But my friends have taught me better. Those women are happy-truly happy. They go where they want, do what they want, act how they want, and they don't ask for permission. I always thought that their freedom was wrong, but it isn't. They embody everything I want for myself, something I thought I could never have.

\section{BRAD}

*Rolling his eyes and starting to walk away* I should have listened to Chad. You are acting ridiculous, and I am over it. You need to fix your attitude and get it together. I am your husband and you will start acting like it! 
*For the first time, KAREN is seeing things in full clarity and realizing the man that she married.*

\section{KAREN}

*Calmly and strongly states* I want a divorce.

\section{BRAD}

*Abruptly turns around, his mouth dropping in shock* You WHAT?! How dare you-

\section{KAREN}

*Harshly interrupts $B R A D$, in a strong tone* No Brad, I'm speaking. I want a divorce. I'm realizing now how little control I've had. Men like you have run my life for far too long. First it was my father, and now it's you, and

I won't spend a moment longer acting like you know what's best for me.

\section{BRAD}

Karen, sweetheart, don't do this. You're brainwashed. It's okay, I'll call the doctor-

\section{*KAREN holds up a hand to silence him.*}

\section{"Get Out and Stay Out" from 9 to 5 The Musical (with original lyrics by Alexandra)}

\section{[KAREN:]}

Well, It's funny how you're standing there, and calling me insane

Well let me tell you something, it is you I blame

Can't you see I'm leaving, or are you still that blind

No - you stand right there and take it, there's no love to hide behind

Well, I am proud to tell you I'm really feeling good.

I'm doing so much better than you ever thought I would.

Want my own place, my own space, to think and dream and plan

Took me this long to realize I do not need a man

I used to need you, but then I finally learned

I used to want you, now the table's turned

I used to love you, now it's your time to squirm

Cause I'm saying goodbye, and I don't want you to return.

So get out and stay out, I've finally had enough

Don't kiss me on your way out, it wouldn't move me much

You used me, abused me, you cheated and you lied

So get out and stay out, I'm taking back my life

I wonder what you'll do when I am not around

Now that I'm here and I plan to stand my ground

You've always come crying to me throughout the years

But now you'll trick another girl, to dry your selfish tears

So get out and stay out, I'm moving on at last

Oh, I've been so foolish, but that was in the past. 
I never thought I'd be the one to say goodbye

You get out and stay out, I'm taking back my life.

Dreams and plans are in the making

Success is out there for the taking

Wish it was as simple as it sounds

I have no choice I have to do it

Face the future, walk into it

Now that I'm unfettered and unbound

Get out and stay out, I've finally had enough

Don't kiss me on your way out, it wouldn't move me much

You used me, abused me, you cheated and you lied

So get out and stay out, I'm taking back my life

My life

*SONG ENDS*

$B R A D$ is shocked and angrily storms out, leaving KAREN triumphant and crying tears of joy. For the first time she genuinely smiles, feeling truly happy.

*END SCENE*

*NEW SGENE*

$K A R E N$ is feeling relieved since she asked $B R A D$ for a divorce. For the first time she has control over her life, and she relishes the feeling. She realizes that she wanted to join the women at NWP and help them gain suffrage and freedom. She decides to go to the women and apologize. KAREN nervously enters and waits for the ladies to acknowledge her presence.

\section{BETTY}

*With a sarcastic smile* Look what the cat dragged in.

\section{BRIDGETT}

What do you want?

*PENNY simply glares at KAREN.*

\section{KAREN}

I just came to talk to you guys and explain myself.

\section{BETTY}

*Folding her arms* We don't want to hear what you have to say! 
*ALICE walks into the room for the first time and looks surprised to see KAREN.*

\section{KAREN}

Please. Give me one more chance. If you don't believe me, I won’t bother you again.

\section{ALICE}

Fine, explain yourself.

\section{KAREN}

I am so sorry. Originally, I joined NWP to give information to the anti-suffrage movement. I wanted to stop women from getting suffrage and changing the family structure, but as I got to know you and your story, something changed. For the first time, I saw things clearly. My husband, Brad, told me that you all were brainwashing me, but I realized it was him and the NAOWS all along. I realized how Brad controlled me, and how unhappy I was. I saw that I want to vote and have a say for myself. I also saw how beautiful and powerful you guys are. You gave me the strength to become a powerful woman, and I am so inspired by you. I want to join NWP for real, because I value what you're doing. Please accept my apology.

*There is silence following her speech.*

\section{BETTY}

*Sarcastically replies* Well, I am beautiful.

*Everyone laughs.*

\section{BRIDGETT}

I accept your apology. And I am sorry I called you a cow behind your back.

\section{PENNY}

*Running to KAREN and throwing her arms around her* Oh, I accept your apology!

\section{KAREN}

*Shyly looking at ALICE* Alice, I'm especially sorry to you. I really appreciate all you did to make me feel welcome here, and I'm so sorry for taking advantage of that. The truth is, I don't think I would have changed if it wasn't for you. So, I understand if you don't forgive me, but thank you for showing me that I can control my own life.

\section{ALICE}

*Smiles* We missed you, Karen. Welcome home. 
*The two of them hug, and the others cheer.*

*END SCENE*

*NEW SCENE*

The women are gathered at the protest with signs and posters. They are all in a group. ALICE speaks with a megaphone.

ALICE

Ladies, are you ready?

*The crowd cheers.*

FINALE: "This Is For My Girls" (with Jadagrace, Janelle Monáe, Kelly Glarkson, Kelly Rowland, Lea Michele, Missy Elliott \& Zendaya)

[BETTY:]

There's beauty in your soul

That's what makes you beautiful

Don't let nobody ever make you doubt it, yeah

[HARRIET:]

Your heart is free and strong

That's what keeps you keeping on

Can't keep you down, there ain't no doubt about it

\section{[ALICE:]}

Don't forget, it's all about respect

Nothing else will do

Remember it's your life

Live it any way you like

Cause you know you got the right to

\section{[ALL:]}

This is for my girls all around the world

Stand up, put your head up

Don't take nothing from nobody

This is for my girls stand up and be heard

This is for my ladies, my sisters, all over

This is for my girls 


\section{[KAREN:]}

You're someone who can be soft as silk but strong as steel

Don't shy away from showing what you're made of, oh

\section{[ALICE:]}

This world is yours to take

You can bend but you won't break

You got no fear and nothing you're afraid of

\section{[BRIDGETT:]}

So don't forget, it's all about respect

Nothing less will do

Take a truthful to your side

Let 'em see how bright you shine

Cause you know it's your time to...yeah

\section{[ALL:]}

This is for my girls all around the world

Stand up, put your head up

Don't take nothing from nobody

This is for my girls stand up and be heard

This is for my ladies, my sisters, all over

This is for my girls

\section{[PENNY:]}

Let life in with open arms

With love and with an open heart

We got to remember

We'll stand strong forever

Yeah, we stand together

\section{[ALICE:]}

This is for my ladies, like soldiers we stand up

Remember when 2Pac told us keep our head up?

And even when the times get rough we get up

Treat your life like a stage, you go 'head and tear it up

Pass the mic, pass the mic, ladies come through

Don't ever, ever let 'em try to stop or try to block you

You better tell 'em you something better than any other You'll never settle, you're next level, yeah, you're making moves

Woo, put your hands up high 
This is U-N-I-T-Y

Yo, yo, this is how it go, woo

\section{[ALL:]}

This is for my girls all around the world

Stand up, put your head up

Don't take nothing from nobody

This is for my girls stand up and be heard

This is for my ladies, my sisters, all over

This is for my girls

This is for my girls all around the world

Stand up, put your head up

Don't take nothing from nobody

This is for my girls stand up and be heard

This is for my ladies, my sisters, all over

This is for my girls

All over, my girls, my girls

My sisters, my sisters

All over, this is for my girls

\section{THE END}




\section{Bibliography}

Cordero, Nick. "You Will Still Be Mine.” Waitress, Original Broadway Cast Recording, 2016.

Porter, Cole. "I Am Ashamed That Women Are So Simple." Kiss Me Katie - Music By Cole Porter, DRG Records, 2000.

Kohn, Ben. "Salute." Salute, Columbia Records, 2013.

Miranda, Lin-Manuel and Kitt, Thomas Robert. "What I Was Born To Do." Bring It On: The Musical, Back Lot Music, 2012.

Foster, Scott Michael and Rodriguez, Vincent. "Sports Analogies." Crazy Ex-Girlfriend: Original Television Soundtrack (Season 4), WaterTower Music, 2019.

Swift, Taylor. "The Man.” Lover, Republic Records, 2019.

Bareilles, Sara. "Brave." The Blessed Unrest, Epic Records, 2013.

Swift, Taylor. "Bad Blood.” 1989, Big Machine Records, 2014.

Parton, Dolly, "Get Out and Stay Out." 9 to 5: The Musical, Dolly Records, 2009.

Warren, Diane Eve. “This Is For My Girls.” My Girls, AOL Makers, 2016.

Utech, Ingrid. Women's Suffrage: Five Facts You May Not Know. 11 July 2020, www.midfloridanewspapers. com/highlands news-sun/women-s-suffrage-five-facts-you-may-not-know/article cf99cf28-c227-11ea9a5c-f73d9ebcc480.html.

Davis, Jennifer. "Mary Ann Shadd Cary: Lawyer, Educator, Suffragist." Mary Ann Shadd Cary: Lawyer, Edu cator, Suffragist | In Custodia Legis: Law Librarians of Congress, 28 Feb. 2019, blogs.loc.gov/ law/2019/02/mary-ann-shadd-cary-lawyer-educator-suffragist/.

Lange, Allison. “Opposition to Suffrage.” History of U.S. Woman's Suffrage, 2015, www.crusadeforthevote.org/ naows-opposition.

Michals, Debra. Alice Paul. 2015, www.womenshistory.org/education-resources/biographies/alice-paul. 